\title{
Sustainability Effort Acceleration as Measured by Increased Propensity of Corporate Social Responsibility
}

\author{
Mark Ray Reavis ${ }^{1}$ \& Jack E. Tucci ${ }^{2}$ \\ ${ }^{1}$ College of Business, University of Central Arkansas, Conway Arkansas, U.S. \\ ${ }^{2}$ William M. Lemley Endowed Chair of Business, Arkansas Tech University, Russellville, Arkansas, U.S. \\ Correspondence: Jack E. Tucci, Arkansas Tech University, Russellville, Arkansas 72802, U.S. E-mail: \\ jtucci@atu.edu
}

Received: October 20, $2020 \quad$ Accepted: November 21, $2020 \quad$ Online Published: November 24, 2020

doi:10.5539/jms.v10n2p121 URL: https://doi.org/10.5539/jms.v10n2p121

\begin{abstract}
Corporate Social Responsibility (CSR) is the foundational bedrock for sustainability efforts. Corporate Social Responsibility is also becoming the norm rather than the exception due to social awareness created by curricula that highlights areas of both social and environmental inequality and has recently emerged as a bona fide strategic option globally. Howe and Straus predicted the growth of Corporate Social Responsibility in their seminal work, Millennials Rising. This paper extends and validates that earlier work through the illumination of recent causal factors and changes in society. The combination of proactive equality initiatives resulting in changes in leadership and value anchoring by college major illustrates that millennials' ethos more strongly align with both social and environmental sustainability philosophies. The forthcoming millennial upheaval, as posited by Howe and Strauss, is evidenced by "strong belief statements" as interpreted by the raters in this study.
\end{abstract}

Keywords: sustainability, corporate social responsibility, strategy, ethics, curriculum, accreditation, AACSB

\section{Introduction}

Education plays a major role in the development of changing perceptions of individuals and eventually society. Institutional changes further reinforce these learned changes by institutions of higher learning and by the governing accrediting bodies that mandate changes. Nearly 25 years ago, the Association to Advance Collegiate Schools of Business (AACSB) (the world's leading business accrediting body) put as one of its required standards the subject of business ethics. This was manifested by many educational institutions either directly by a required ethics course(s), or the infusion of the ethic topic in several of the required core courses within each program of study.

More recently, the 2020 AACSB standards are now 1/3 fully comprised of the "Standard 9" requirement that each institution shall have "Engagement and Social Impact" measures which specifically address corporate social responsibility not only in the educational core of the program, but also as an active component in the education of the students through "hands-on" community projects as service-learning initiatives. Most progressive business schools participate and focus on business schools students' active engagement of social and environmental programs with a focus on sustainability (Stonkute et al., 2018; Larran et al., 2018). These progressive schools actively engage in Enactus that wholly promotes Sustainability and Social Responsibility as its main themes. Often manifested as "service learning" many schools either require a minimum number of hours of service, or award diploma citations/notations to the student who maintain a specified level of participation (Miftachal et al., 2018). The AACSB Standard 9 is as follows (AACSB.edu):

\section{STANDARD 9: ENGAGEMENT AND SOCIETAL IMPACT}

9.1 The school demonstrates positive societal impact through internal and external initiatives and/or activities, consistent with the school's mission, strategies, and expected outcomes.

\section{Definitions}

- Societal impact refers to how a school makes a positive impact on the betterment of society, as identified in the school's mission and strategic plan. Societal impact can be at a local, regional, national, or international level. 
Figure 1 Standard 9

A significant number of international schools of business research incorporate social responsibility (CSR) and it is expanding at a rapid rate (Ferrell, Thorne, \& Ferrell, 2016; Prutina, 2016; Serban, 2015). Curriculum is being reengineered to take full advantage of the benefits of this new approach to strategically manage business schools in general and business specifically (Horng et al., 2019). The ability to develop sustainable goals while improving societal imbalances is paramount (ElAlfy 2020). This has shifted the focus from a stockholder approach to a stakeholder approach in response to societal changes (Reavis et al., 2017; Rogers et al., 2020).

Howe and Strauss' posit that millennials perceive an ethical duty to reengineer society and become change agents. The term 'millennial' is used in this research to refer not only to a generation of young people by age, but also to their worldview and society's perception of them. By age, this generation was born approximately 1982-2000. This is the sample boundary used in this study. Millennials worldview is much more social-oriented than their parents or grandparents. They are activists and seek to make the world a better place. Society regards this generation as special and as having a capacity for greatness (Howe \& Strauss, 2000). "The Millennial future is what America is destined to become" (Howe \& Strauss, 2000, p. 367).

\subsection{The Model}

The literature and global business school accreditation standards (AACSB) makes it obvious, even to interested casual observers, there has been a sea change in business school strategies. Schools have evolved from a pure ethics focused curriculum and transitioned to a Corporate Social Responsibility model by the early 2000's. Nevertheless, this evolution has continued and is maturing on a focused sustainability ethos of decision making in the second half of this decade. The model for this evolution is depicted below with the drivers of the changes providing the upward forces exerted that are pushing the evolution of thought about people, profit, and planet to its maturity.

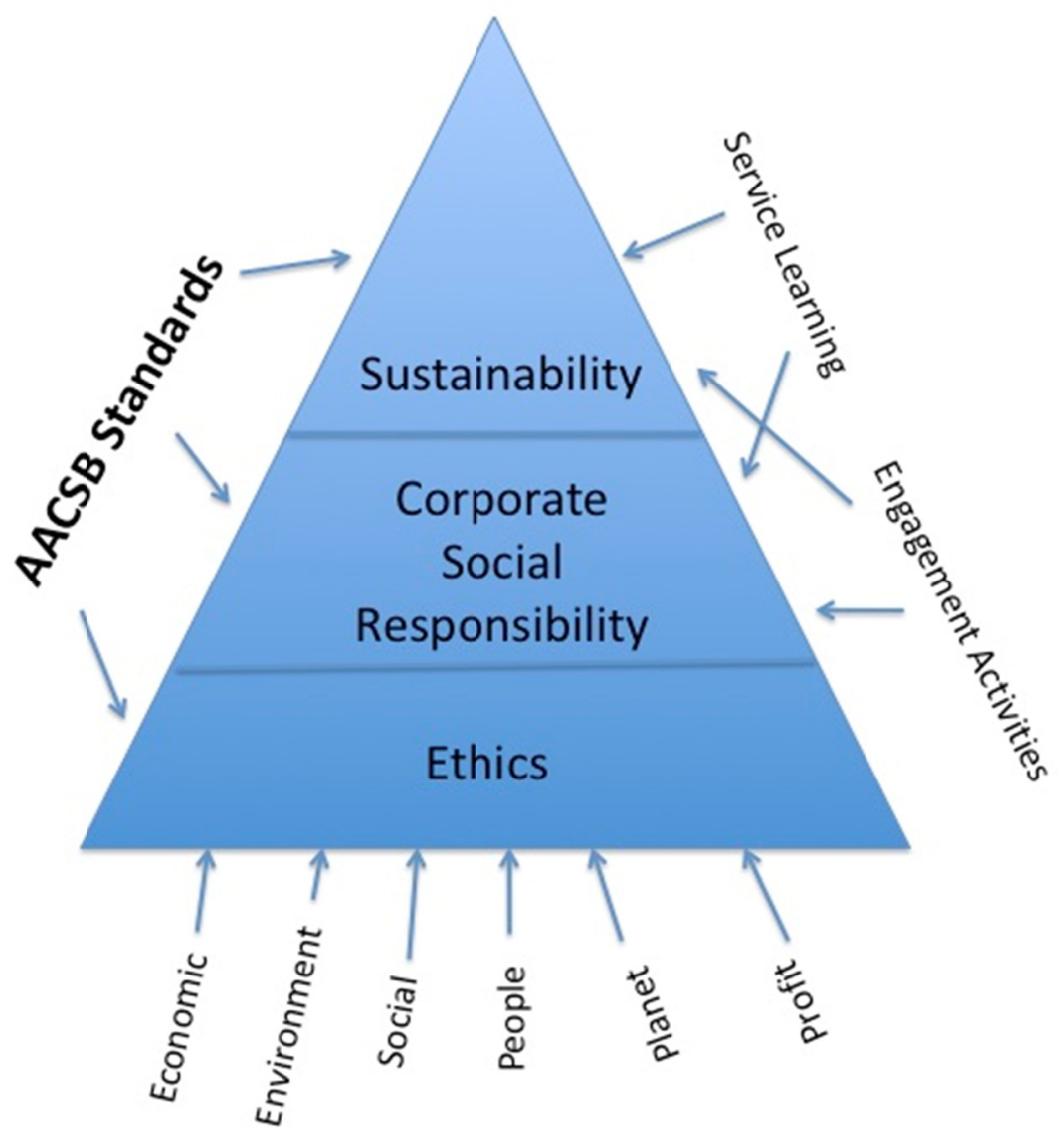

Figure 1. Evolution towards sustainability: The efficacy of change in accreditation standards 
This model contends that this evolution of thought has occurred at different rates at different times, however the velocity of change has increased and will continue to accelerate even more so when the current generation of millennials emerge in the "C" level suite as they are now. From the efforts of AACSB in the early 1990's requiring ethics in the curriculum, to the further requirement of CSR in the early 2000's as reflected by service learning initiatives, the natural outcome is the emerging sustainability model and Certified type B corporations.

Because millions of dollars and countless person-hours have been spent to change the trajectory of business education, it warrants that the recent past data need a closer look to determine both the efficiency and effectiveness of these changes in the curriculum. It is believed, that if the curriculum is truly impactful, then the predictions by the Brookings Institute bears closer watch (Winograd \& Heis, 2018). Initially data were analyzed to discover that millennials clearly have a strong leaning towards a stakeholder approach. A more fine-grained approach was performed in an effort to discover what factors play a larger part in the emergence of this phenomenon. Rogers et al. (2020) identified that there is a significant difference between females and males perspective in making business decisions about CSR. It was also discovered that that difference between genders was declining over time. Nevertheless, it is accepted in the literature that CSR decisions stem from a values proposition (Ferrell et al., 2016; Serban, 2015). However, the question remains, will those who emerge in the positions of future leadership take a stronger CSR approach to leadership and a resulting change in focus on sustainability? If those positions of leadership are filled by a specific type of business major the question will be, will there be a difference in how those strategic decisions will be made? If this is accepted, then it stands that if there is an ascendant major whose values are significantly different than the current baby-boomer's values, it should be expected that climatic changes in strategic directions to accomplish a sustainability strategy will occur in the near future.

\section{Literature Review}

\subsection{Stockholder and Stakeholder Theory: Contrasting Perspectives}

Smith and Ronnegard in 2016 emphasized that Adam Smith's writing in Wealth of Nations, laid the foundational concepts that stockholder's must be held in the highest regard in all business decisions because they risked personal capital for the profits of invested business. Because of this the stockholder as "risk taker without recourse" (as opposed to lenders who have 1st rights in bankruptcy) must receive the highest consideration when business managers act as agents of the investors. Further, stockholder theory contends that it is the "individual risk taker" who has the right to engage in social responsibility actions/behaviors of her choosing.

A business, on the other hand, does not have the right to engage in social responsibility actions/behaviors because to do so would divert the profits from the rightful owner to a "cause" the owner may or may not support (Smith \& Rönnegard, 2016). This stockholder approach philosophy was strongly supported by the very outspoken Milton Friedman (1970) when he stated, "there is one and only one social responsibility of business - to increase its profits so long as it stays within the rules of the game". Smith and Friedman acknowledge that a business cannot pursue profits at any cost, but must deal with "externalities" or rules, and quantifiable analysis supports their position (Lopez, Garcia, \& Rodriquez, 2007).

For those in favor of CSR, there are other benefits to the stakeholder approach that capture our attention (Aquilera et al., 2007). The Stanford Research Institute defines "stakeholder" as "groups without whose support the organization would cease to exist" (Freeman, 1983). Stakeholder theory as championed by Freeman, came to be defined as "an identifiable group or person who can affect the achievement of an organization's objectives or who is affected by the achievement of an organization's objectives" (Freeman, 1983). The literature provides ample evidence that documents an increase in employee affective commitment when companies are engaged in CSR (Prutina, 2016). Stakeholder includes employees, suppliers, vendors, customers, creditors, government entities, resource communities, etc. (Post, Preston, \& Sachs, 2002). While stakeholders are equal, they are affected by the business' operations and the business is obligated to provide value to these various stakeholders to some degree at the expense of stockholder risk (Rausch, 2011).

\subsection{The Efficacy-Equality Dilemma of the Stakeholder Approach and Sustainability}

The balanced scorecard approach is a method of quantifying the results of business decisions in various identified areas in a semi-holistic approach. The scorecard is used by a wide range of entities, from business to government to military to nonprofits and is a planning and management tool that align activities with organizational goals and missions (Cokins, 2013). The Balanced Scorecard Institute (BSI) helps organizations develop a scorecard for their organization through the development of a framework of nine steps organized around four core components: Customers/Stakeholders, Financial/Stewardship, Internal Processes, and Organizational Capacity (9 Steps to Success, 2017). 
The Triple Bottom Line (TBL), another approach to measuring CSR, was mainstreamed by John Elkington's book (1997) Cannibals with Forks: The Triple Bottom Line of 21st Century Business. The key aspect is the sustainability of the business through performance in financial, social, and environmental areas (Slaper \& Hall, 2011). The concept is simple; along with the Profit-making operational decisions of a company, there are two other operational areas to address: People and Planet. These three combined provide the basis foe the 3P model.

While there is still not a universal TBL that fully addresses sustainability, companies are finding that it is useful in showcasing their Corporate Social Responsibility initiatives; Proctor and Gamble, General Electric, Unilever, $3 \mathrm{M}$, McDonalds, and others have provided TBL reports to the public (Slaper \& Hall, 2011). Wilburn and Wilburn (2015) advise that a 2010 study showed that companies that have proof positive CSR programs enjoyed higher sales among global customers that were willing to pay more for their products.

A Certified B Corp is a company that has been certified by the independent, non-profit organization B Lab that co-founded in 2006 by three entrepreneurs (Honeyman, 2015). Their mission was to create a corporate entity that was both about maximizing wealth and positively impacting society and the environment through sustainability initiatives. B Lab established a set of guidelines for businesses to be certified through a 4-step process. The first-step is to describe their public benefit they are pursuing (B Lab, 2017). It could also be a specific public benefit that addresses such topics as unemployment, nutrition, education, etc. The second step is to assess their overall social and environmental impact using an accepted third-party standard for their industry that meets the criteria listed below (B Lab, 2017). The third step is to identify the company officer(s) who will ensure the company follows its stated goals for the company. B Lab specifically directs that the company's Benefit Director has a duty to consider the impact of business decisions on a variety of interests. B Lab's (2017) list of interests includes:

(i) the stockholders; (ii) the employees; (iii) customers; (iv) communities; (v) the local and global environment; (vi) the short-term and long-term interests of the benefit corporation, and (vii) the ability of the benefit corporation to accomplish its general public benefit purpose and any specific public benefit purpose.

Finally, in the fourth step the company must name every person who owns more than five percent of the company. The benefits of B Lab certification include greater stockholder rights, reduction in director liability, access to increased private capital investment opportunities, greater and faster investor access while preserving the company's mission, attracting talent, a reputation for leadership, and a promise of what future Fortune 500 companies look like (B Lab, 2017). A study in 2015 of the forty-five original Certified B-Corps companies found that all made progress toward their stated goals, were profitable, and had published annual reports for greater transparency (Wilburn \& Wilburn, 2015).

\subsection{Barriers}

Legal challenges to Certified B-Corps emerged in September 2009 when EBay won a lawsuit against Craigslist that legally restated that the sole function of a business is to maximize stockholder wealth and that other considerations were always secondary to that maxim (Gilbert, 2010). Thus, one of B-Lab's first projects was to develop a legislative model for states that decide to add the Benefit Corporation as a business entity to their state's laws regarding the formation of business. As of 2019, thirty-four states and the District of Columbia have enacted Benefit Corporation legislation (Benefit Corporation, 2019). This legally allows the designated company to operate in a manner that does not require the company to pursue maximization of stockholder wealth at the expense of public benefit (El Khatib, 2015).

A primary issue is the lack of compliance provisions regulating Benefit Corporations. Most states with Benefit Corporation laws have no defined consequence for the corporation if it fails to meet its stated purpose benefits. Additionally, the company cannot be sued for failure to pursue or archive the intended benefit except by a stockholder, a director, or a person who owns more than five percent of the company - and then only under very specific circumstances (ABC Act, 2013). Unlike traditional for-profit corporations, Benefit Corporations (which are still in the business to make a profit) cannot be held accountable for business practices by stockholders unless there is a question of the company pursuing its stated benefit goals (Hacker, 2016). To address this issue, Hacker (2016) recommends supplementing the laws detailing that the states' Attorney General Offices be tasked with ensuring the compliance of Benefit Corporations with striving to meet their public benefit goals.

Lastly, the existence of B-Corps certification begins to create an illusion for consumers that they are automatically more socially responsible than traditional for-profit corporations. This perspective bias could theoretically create an unfair advantage much to the detriment of a traditional company. 'Greenwashing' is defined as "use of a public-relations-enhancing social purpose to fritter away money without oversight" 
(Solomon, 2015). Hacker (2016) and El Khatib (2015) both refer to greenwashing as using the labels that convey to the consumer the company is engaged in a public benefit when in actuality it is just a complex marketing ploy and there is no substantive effort by the company or results from efforts to actually pursue the stated public benefit.

\subsection{CSR and Sustainability Internationally}

The CSR movement is growing internationally (Ferrell et al., 2016). In 2007, 45 companies became founding B Corps. These companies were all from Canada and the United States (Wilburn \& Wilburn, 2015). As of March 2019, there were over 2,500 Certified B-Corps in 50 countries (B Lab, 2019). More importantly to drive home the point how is accelerating; there has been a not insignificant increase of nearly $50 \%$ in both B Corp companies and countries utilizing this form of incorporating in the last year alone. So far in 2020 there are 3585 companies in 74 countries that are utilizing the B Corp form of incorporation. This upturn in CSR-Sustainability focus reflects the growing awareness and acceptability that there is more than profit to business.

Australian law may illustrate one of the challenges to B-Corp Certification. In Australia, directors are bound by a strict duty to do what is best for the company. As a result, considering the impact of business decisions on other stakeholders can be considered as a breach of fiduciary duty. Directors considering stakeholder concerns may find themselves subject to personal liability. Although Australian law does not prohibit corporations from considering social benefits, there is little emphasis on this and directors are generally not focused on stakeholder issues. Australia continues to struggle with an appropriate method for addressing the CSR issue (Achermann, Forde, \& Ouzas, 2014).

India is completely on the opposite side of the CSR issue contrasted to Australia. In 2013, India passed the Indian Companies Act 2013, an amendment to India's laws governing corporations. This Act included a specific requirement for Indian companies to spend at least $2 \%$ of their average earnings on CSR activities. To be required to comply with this new law, a company in India must meet certain revenue and/or asset thresholds. To comply, a company may spend its earnings on such issues as hunger, poverty, education, child mortality, or maternal health (Hiralal, 2015).

In 2015, Italy became the first foreign nation to make Benefit Corporations legal entities; similar legislation is also being advocated in Australia, Argentina, Chile, Colombia and Canada (Benefit Corporation, 2019).

\subsection{Future Leadership and the Millennial Perspective}

This literature review has described relevant theory and practice with regard to CSR and resulting sustainability. The results of this study seek to add to the existing body of knowledge by providing evidence of millennials' philosophy and attitudes on CSR with a focus on differences by major. The 1982 to the year 2000 is the most commonly accepted period for the millennial generation. Although the exact dates are unclear the approximate range of early 1980's to about 2000 fits with most published estimates (McGlone, Spain, \& McGlone, 2011). This generation is playing an important role in CSR because they will significantly influence society toward a more stakeholder centered approach.

Millennials are perceived by other generations as being optimists, cooperative, and civic minded. They "will demand that employers adjust to the needs of workers who wish to build careers and families at the same time.... Fair Play on pay and benefits will be at issue" (Howe \& Strauss, 2000). Millennials will not only demand changes in the workplace that focus more on their needs instead of their employer's needs, they will also tend to seek out and buy "products that combine their focus on family... and community approval" (Howe \& Strauss, 2000). Millennials are activists. They will seek to influence community, political, economic, and environmental issues (Howe \& Strauss, 2000). This leads us to the assumption that sustainability through corporate CSR efforts will be the "natural" outcome of this generations influence and future leadership.

\subsection{Self Perceptions and Life Goals Leading to Sustainability Efforts}

Millennials are largely misunderstood in the workplace today. They are often viewed as lazy, entitled, and never satisfied (Roker, 2017). Millennials have a different self-perception. They view themselves as ambitious, innovative, connected, and expressive. Millennials are "looking for things to support because we want to feel like we're making a change in the world" (Roker, 2017). For millennials, actions are important. They seek to reward or punish corporations based on CSR involvement (McGlone et al., 2011).

Millennials also perceive that doing good is not enough, that authentic leadership is critical (Kim et al., 2018). Authenticity is manifested by the internal controls to define the internal structure defining the roles and interactions within the firm. It is not doing good for external measures, it is doing good because it is what the 
organization is at its core. This is an effort to prevent the greenwashing evidenced by firms who in times past "were not fully committed to the ethos of sustainability and lacked authenticity" (Tucci, Shin, \& Benefield, 2015).

Since millennials seek more than profit, they are likely to change the corporate culture as they move into positions of senior management and run their own companies. This will sift the corporations towards sustainability models. They want corporations to have a social conscience (Sharp, 2014). Millennials have become the largest generation in the U.S. labor force making up 35\% of the total U.S. labor force (Arkansas Business, 2018). Over half of the workforce will be composed of millennials by 2025 . They will seek changes in society and they will have achieved societal critical mass and its associated power to effect change. This current age grouping seeks to advance societal welfare over individual success (Winograd \& Hais, 2014). However, these demanded changes are not balanced. Prutina (2016) identified that as individuals rise in position and authority and are engaged in CSR, organizational commitment increases. What remains to be seen, is why is this phenomenon is increasing? This study contends curricula and culture have coincided. This paper reinforces that this rise of millennials and the make-up of the future corporate leadership class illuminates the force behind the change.

Concurrently, the gender leadership ratio is occurring simultaneously (Rogers et al., 2020). Women see both a higher level of organizational commitment and commitment to their personal values than men as they rise within the organization (Aggarwal, Dhaliwal, \& Nobi, 2018). As the baby-boomers age and as turnover increases and women ascend the corporate ladder into executive leadership, the expected change will be in CSR resulting in increased sustainability efforts and commitment to that as a strategy. The corresponding lower likelihood of being replaced as a corporate leader in uncertain times will entrench these new leaders into the social fabric of these corporations (Cooper, 2017). Evolutionary factors such as increases in board diversity and changes in strategy are becoming the norm (Rao \& Tilt, 2016; Marques-Mendes \& Santos, 2016).

In the Methodology section to follow, the comments of millennial students from Business Finance classes (required of all business majors where data were collected) during 2014-2018 period were analyzed. The majority of the students' comments strongly identify with stakeholder theory versus stockholder theory. In their own words, shown below, students state how they feel about CSR.

* If the company is able, they should do what they can for their society.

* I want to live in a world where we feel responsible for the bettering of other people.

* The idea that a corporation does not owe anything to the community that it serves is unethical.

* Social Responsibility is here to stay and for good reason.

* The Social Responsibility that a company shows to their customers far outweighs any amount of profit.

* America without social responsibility would not be America.

* I believe it is in the best interest of the corporation to involve themselves in social responsibilities.

* A company that values customers and the communities in which they serve is way more successful than the company with the largest profits.

* Social responsibility should be embedded within every individual, member, group, organization, corporation, and governmental entity in our society to effectively make a change.

After the initial analysis and following the publication of previous research on this topic, it was evident that at least one other factor in the data might provide better insight as to why/how the earlier results were significant. The data were broken down into component factors and analyzed for significance to either Stockholder or Stakeholder preference. Then, it became clear to the researchers, upon a cursory visual observation of the data that a "college business major" difference existed in the data.

\section{Methodology}

Millennial students were selected for this study as appropriate to test the prediction that they would have a greater propensity to seek the common good, be more socially conscious, and take a more active role in society and politics that clearly follows the concepts of sustainability empowered by CSR than previous generations. To determine if Millennials' do have a heightened sense of CSR as reflected in a philosophy of "better for the common good" students attending a senior level business class 2014 through 2018 were sampled. From 2014-2018, a total of ten semester's data was collected and analyzed from multiple universities, using the same discussion assignment to generate student comments. The sampling came in the form of a Blackboard discussion 
assignment to supplement both in-class and on-line education.

The assignment was set so that the students' first comment was their philosophy and beliefs about the difference between the public Starbuck's corporate video which has high levels of stakeholder approach to corporate governance and compare that to a required reading from Milton Friedman where he presents the stockholder approach and focuses on the theory that the sole purpose of business is to increase its profits (Friedman, 1970). The Starbucks stakeholder philosophy can be summed up in a quote from Joseph Michelli (2007) from his book, The Starbucks Experience, in which he states, "The biggest story at Starbucks is that it's as much about people as it is about coffee" (p. 11). Figure 1 shown below is an excerpt from the instructions for the class discussion assignment. Students are blind to everyone else's initial post so as to not prejudice/bias them in their initial post. Only after entering their initial post can students see others initial and subsequent post.

To complete this assignment, you must:

- $\quad$ Read the Milton Friedman article, 'The Social Responsibility of Business is to Increase its Profits' - the article is posted below these Discussion Instructions.

- Watch the Video of the 2012 Starbucks Annual Stockholders Meeting - a link to the video is posted below the Friedman article.

- Enter the Discussion 'Corporate Social Responsibility' and post your discussion information based on the following:

-Your First Post - should describe how you feel about the issue. Should corporations adhere to Friedman's philosophy or follow Starbucks' example regarding corporate social responsibility? Why?

-Your Subsequent Posts - should respond to other posts from the class.

Figure 2. Discussion board instructions

Blackboard was set-up so that the students were not allowed to read other students' posts without first stating their opinion/philosophy about their thoughts and values. Once the initial post was recorded and students were allowed to continue with the discussion, the discussion boards were archived for later evaluation. Students that met all the published standards and whose birth year fell within the commonly accepted timeframe of mid-1980's - 2000 were used. Students who were older or younger than that millennial age were eliminated from the data set. (It was noted that older students by a wide margin did prefer the stockholder approach to management). For this study, 197 business majors completed this assignment as described. These students were categorized by the semester in which they attended over a five-year period. This way of categorizing students yields 10 semesters of data over a five consecutive year period.

All of the initial comments were aggregated, and three copies were made and given to three raters. As always, inter-rater reliability is an issue. The ICC3 test (also known as Cronbach's Alpha) was used to test the reliability of raters not only individually, but collectively as a group. The ICC3 score for the three raters used in this study was .9742 which is considered very high in reliability. On the cross-sectional scale comparing each of the overall averages of the raters, the averages were $-.79,-.86$, and -.83 respectively. Table 1 contains the results of both the Cronbach's Alpha test and the Pearson's r calculations for each pair comparison as well as the mean of the Pearson's $r$ as is commonly accepted measure of reliability between rater pairs. 
Table 1. Inter-rater reliability statistics

\begin{tabular}{ll}
\hline ICC3 and Pearson's r & Calculation Results \\
\hline ICC3 (Cronbach's Alpha) & .9742 \\
Pearson's 1\&2 & .89445 \\
Pearson's 1\&3 & .94433 \\
Pearson's 2\&3 & .94010 \\
Mean Pearson's $\boldsymbol{r}$ & .926595 \\
\hline
\end{tabular}

The researchers found no gender inter-rater bias in the analysis as this might have been a concern using multiple genders in the analysis. After individual ratings had been accumulated and input into a spreadsheet, a scatterplot of the data was evaluated to determine if there were any anomalies and/or associations that could be immediately identified. The following scatter-plot Figure 3 is provided below.

The next step in data parsing was to organize the data set into comparison groups for study. We used a semester format since it roughly organizes students to be studied about the same time for each age group over the course of this research. Students falling outside of the 1982 to 2000 birth years were not used in the analysis (Howe \& Straus, 2000). It was noted that during the initial rating phase of the study in determining the stakeholder-stockholder perspective, there appeared to be a difference in responses based on declared major. Interestingly, what we classified as "quantitative majors," (accounting, finance, economics and, data analytics) appeared to be different than those of we classified "qualitative majors" (management, marketing, human resources, and business administration). We used these two classifications; Quantitative and Qualitative Major for the remainder of this study. In our coding we used Quan to represent those students whose declared major was a quantitative (heavily math based). We used Qual to represent those students whose declared major was qualitative by nature (heavily social/behavioral sciences)

\section{Results}

The amount of data (591 data points across 5 rating lines) highlights the propensity for the students to more closely associate with the stakeholder approach. The researchers found a high level of reliability in the predictive power of the results. The $\mathrm{P}$ value of $\mathrm{P}=.0086801$ gives strong evidence that the difference in Qualitative Business Majors (stakeholder approach) and Quantitative Business Majors (stockholder approach) preference is significant. Although the number of respondents was limited in two of the ten observation series (semester distribution), the overall variance for Qualitative majors was .277 whereas the variance for Quantitative majors was .273 giving the researchers great confidence in the results of their analysis and conclusions.

Table 2. Data reliability statistics

\begin{tabular}{|c|c|c|c|c|c|c|}
\hline \multicolumn{7}{|l|}{$\begin{array}{l}\text { Anova: Single Factor } \\
\text { SUMMARY }\end{array}$} \\
\hline Groups & Count & Sum & Average & Variance & & \\
\hline MG/MKT & 10 & -9.258225108 & -0.925822511 & 0.277175727 & & \\
\hline FIN/ACC & 10 & -5.007539683 & -0.500753968 & 0.273496278 & & \\
\hline \multicolumn{7}{|l|}{ ANOVA } \\
\hline Source of Variation & SS & $d f$ & $M S$ & $F$ & $P$-value & F crit \\
\hline Between Groups & 0.903416329 & 1 & 0.903416329 & 3.2811413 & 0.008680 & 3.006976 \\
\hline Within Groups & 4.956048046 & 18 & 0.275336003 & & & \\
\hline Total & 5.859464376 & 19 & & & & \\
\hline
\end{tabular}




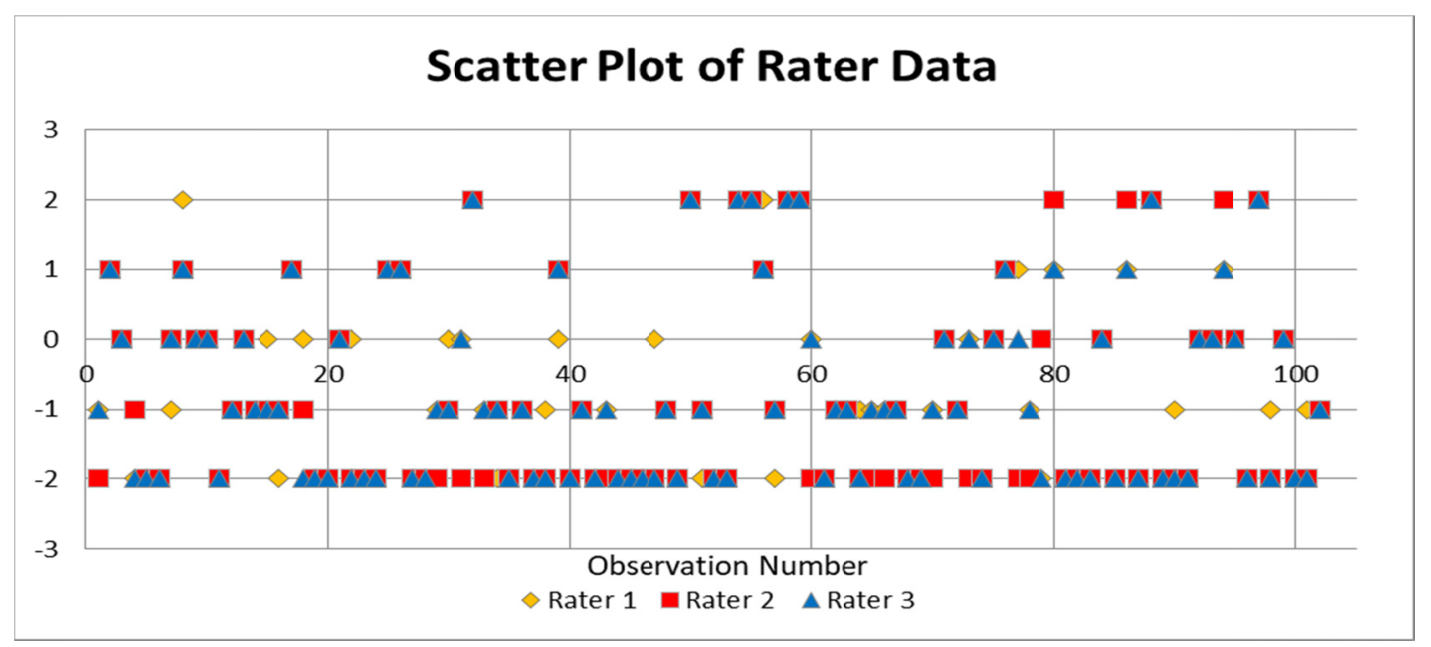

Figure 3. Intra-class correlation dot plot

A more poignant way of looking at the data is to look at the five categories graphed by percentages by alignment. The scale used by the raters varied from -2 to +2 . The -2 end of the scale represents an alignment of values as espoused during the Starbucks annual meeting of stockholders. On the other end of the scale is the +2 which represents an alignment of values with what Milton Freidman (1970) espoused in his treatise. The -1 and +1 represent points along that continuum representing the support of one or the other approaches to corporate governance. Table 3 was used by the raters to categorize the Millennials' response in their initial Blackboard post.

Table 3. CSR discussion post ratings

\begin{tabular}{llll}
\hline Starbucks & Starbucks & Neutral/Balanced & Friedman \\
\hline-2 & -1 & 0 & +1 \\
\hline Strongly supports & Lean toward Starbucks' & Neutral or balanced. & Lean toward Friedman's \\
Starbucks' philosophy & philosophy, & No strong preference for & philosophy, \\
with no reservations. & but with some & one philosophy over the & but with some \\
& reservations. & other. & reservations. \\
\hline
\end{tabular}

After categorizing the data into each category, Chart 1 illustrates by percentage the strength of the stakeholder philosophy shared by Millennials. 


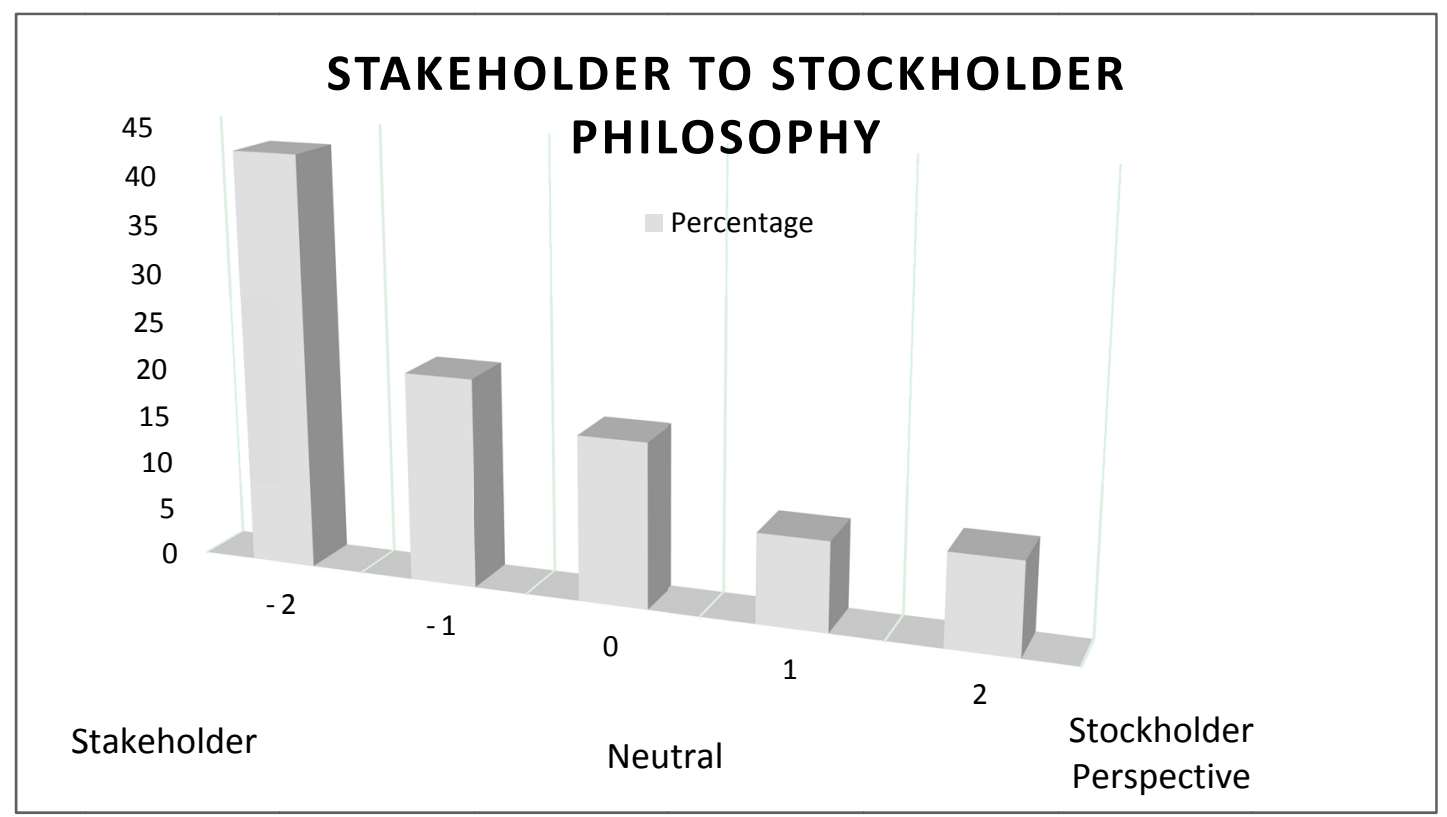

Figure 4. Student philosophy by rating

A full $52.5 \%$ of all millennial students "Strongly Support" the Starbucks stakeholder approach to corporate governance. When added to the moderate support or leans towards Starbucks stakeholder approach, more than $71.25 \%$ of Millennials' identify as Stakeholder oriented. In comparison, only $17.68 \%$ (total of both strongly support and lean towards) of Millennials' share Friedman's stockholder approach to corporate governance. Those that were neutral, not preferring either the stakeholder or stockholder approach, or preferring both, represented only $11.0 \%$ of the sample.

\subsection{Millennials by Academic Major}

The data were further broken down by its essential components of gender, major, and semester as self-identified by the student, recorded in the data collection process verified by cross checking with the university's data system. A graph was initially used in an initial effort to see which variables might best explain the strong bias towards a stakeholder approach. It was immediately evident, that clusters of academic major observations indicated a potential reason for the propensity of CSR. The difference between Academic Majors was significant. Although both academic major classifications (qual and quan) were weighted towards a stakeholder approach, the consistency towards the stakeholder approach was much stronger for the QUAL major groups as compared to the QUAN majors groups. Nevertheless, those differences were declining over the time period under study.

Census data show that millennials constitute the largest percentage of the workforce by generation (Arkansas Business, 2018). It is only a matter of time before millennials will obtain "c-suite" level positions in corporations. This groundswell of change in leadership will lead to increased commitment to CSR as predicted by Howe \& Strauss (2000) and supported by recent literature. In addition, the fact that millennial representation is increasing in management and boardrooms and millennial Quals are more strongly supportive of CSR than millennial Quans, their value-anchored approach to CSR will likely lead to greater adoption of CSR focused strategic management. As Marc Benioff (2016), CEO of Salesforce.com has stated, "It's the right thing to do. We are currently moving from a world where its all about being shareholder based to a world where its about stakeholders." 


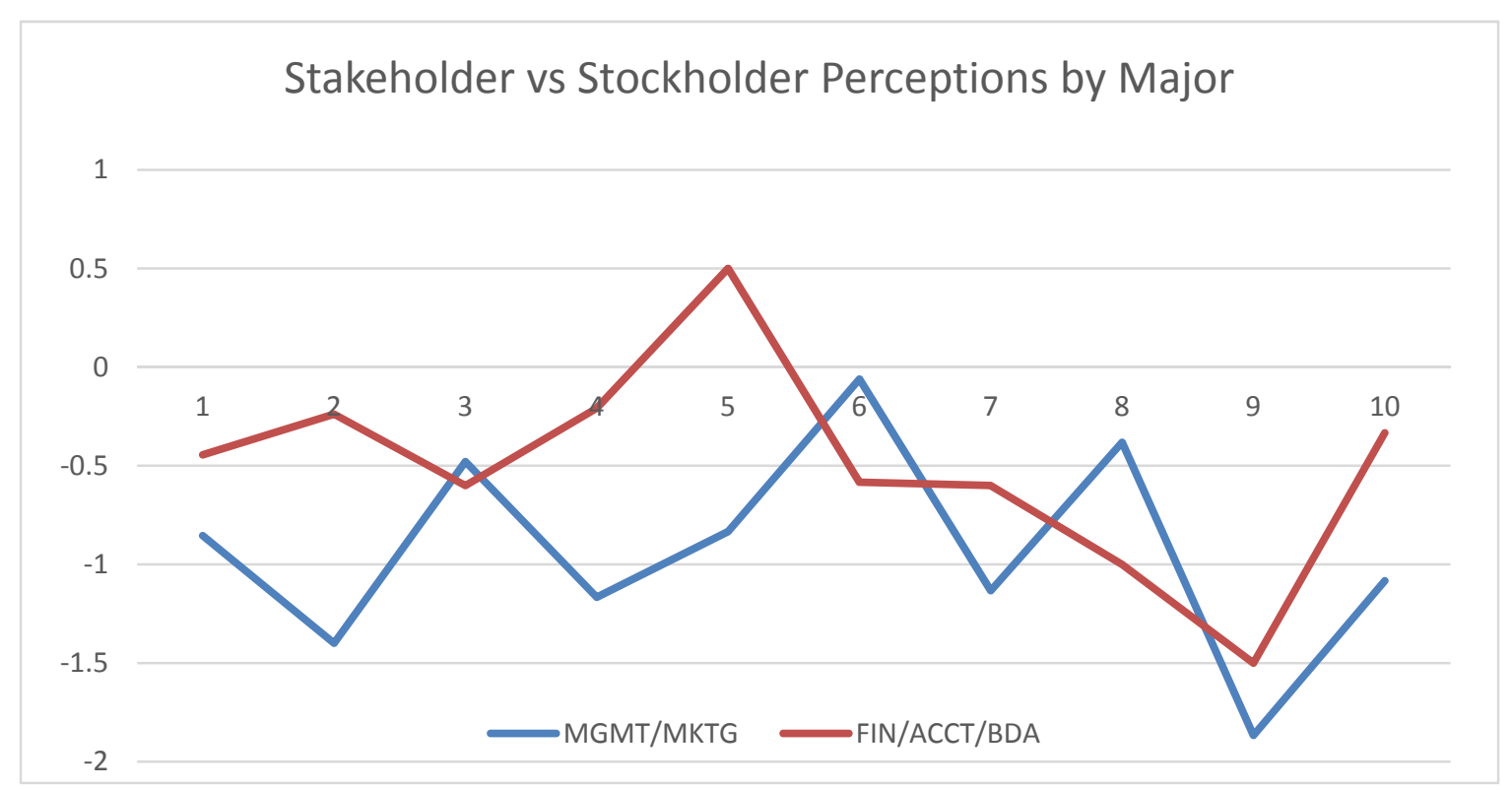

Figure 5. Stakeholder vs stockholder perceptions by major classifications

Once the data were evaluated visually, an ANOVA test was performed to see if there was significance in the two variables. Interestingly, even with two of the ten semesters having statistical issues with small sample sizes for Quantitative Business Majors those semesters (semesters 2, and 9), the overall average for Quantitative business majors was -.5 which is very close to being neutral over this 5-year period with trend towards a stakeholder approach. However, Qualitative Business Majors during this same time period averaged -.93 that indicated a stronger proclivity towards a stakeholder approach that also increased over the period under study. The one unmistakable observation was that both lines during this five-year study trended towards a stronger propensity of a stakeholder approach.

\subsection{Limitations}

The use of the terms such as CSR, Stakeholder Theory, and Stockholder Theory especially when used in conjunction with Sustainability, as used in this study become commonplace and issues of construct validity may have given rise to error in differences in either interpretation or definition by either researchers or respondents. Another confounding variable may be that the class in Business Ethics required of the students before or during taking the Business Finance class in which the data were collected for this study may influence their view of CSR which would naturally extend to sustainability. Lastly, the limited geographic region from which a majority of the respondents live typically is limited. Further studies of Millennials' in other geographic regions could be tested to minimize this potential limitation. Further study of Millennials as they age, marry, work, and support themselves financially could result in changes to the conclusions of their generational philosophy as a whole. The data have now been taken at multiple universities, but there is ample opportunity to test this on a larger data set, preferably multi-nationally.

\section{Conclusions}

Howe and Strauss (2000) postulated that the millennial generation would have higher levels of social consciousness. Our research confirms Howe and Strauss, but extends that research by illustrating that academic majors more closely aligned with social sciences (organizational behavior and psychology), in general, have a higher propensity towards a stakeholder approach to management. Nevertheless, even the quantitative business majors also have a propensity towards CSR and it is increasing. We believe it is increasing due to accreditation requirements and the very nature of the teaching materials and cases available to professors in AACSB accredited schools.

The CSR ratings of millennials' comments found in this study clearly support the assertion that this generation has a predominant stakeholder philosophy. The stakeholder approach preference by qualitatively oriented business majors gives evidence to the power of organizational behavioral perspectives and the associated increase in commitment to organizational change as millennials advance in both scope and role within 
organizations as postulated by Aggarwal, Dhaliwal, \& Nobi (2018) and Prutina (2016). The analysis presented indicates that as more millennials ascend to leadership positions in authority, there should be a corresponding change from a stockholder to stakeholder approach in corporate governance.

The millennial generation, regardless of academic major, strongly support social accountability by those who interact with them in any environment; whether it be in family, politics, or business. The desire of the millennial generation to support the common good and to effect changes necessary to satisfy their social conscience also lends support to the further predictions by Howe \& Strauss (2000) that as they continue to enter the C-level suite it will lead to significant cultural and strategic changes in the fabric of commercial institutions. As a result, sustainability will be required, not expected.

\section{References}

AACSB.edu. (2020). Standard 9 and Societal and Engagement Impact.

ABC Act (ARKANSAS BENEFIT CORPORATION ACT, Ark. Stat. Ann.§§ 4-36-101-401). (2013). Retrieved http://www.arkleg.state.ar.us/assembly/2013/2013R/Pages/BillInformation.aspx?measureno=HB1510.

Achermann, C., Forde, B., \& Ouzas, M. (2014). Benefit corporations-A case study of the US and lessons for Australia. Social Impact Hub B Lab Report. Retrieved from http://www.socialimpacthub.org/wp-content/uploads/2015/01/2014-B-Lab-Report.pdf

Aggarwal, A., Dhaliwal, R., \& Nobi, K. (2018) Impact of Structural Empowerment on Organizational Commitment: The Mediating Role of Women's Psychological Empowerment. Vision, 22(2), 284-294. https://doi.org/10.1177/0972262918786049

Aguilera-Caracuel, J., Guerrero-Villegas, J., \& García-Sánchez, E. (2017). Reputation of multinational companies: Corporate social responsibility and internationalization. European Journal of Management and Business Economics, 26(3), 329-346. https://doi.org/10.1108/EJMBE-10-2017-019

Arkansas Business. (2018). Millennials Constitute 35\% of U.S. Labor Force. Retrieved June 9, 2018 from http://www.arkansasbusiness.com/article/122227/millennials...t=daily-report\&utm_campaign=newsletter\&e news_zone $=3818$

B Lab. (2017). B Corporation. Retrieved from http://www.bcorporation.net.

B Lab. (2019). B Corporation. Retrieved from http://www.bcorporation.net.

B Lab. (2020). B Corporation. Retrieved from http://www.bcorporation.net

Balanced Scorecard Institute. (2017). 9 Steps to Success. Retrieved from http://www.balancedscorecard.org/Resources/The-Nine-Steps-to-Success

Benefit Corporation. (2019a). State by State Status of Legislation. Retrieved from http://benefitcorp.net/policymakers/state-by-statestatus

Benefit Corporation. (2019b). International Legislation. Retrieved from http://benefitcorp.net/international-legislation

Benioff, M. (2016). From CBS This Morning June 1, 2016.

Chalmers, A. W., \& Onna, M. v. d. B. (2019). Financial volatility and public scrutiny as institutional determinants of financial industry firms' CSR. Business and Politics, 21(2), 240-266. https://doi.org/10.1017/bap.2018.28

Cokins, G. (2013). Kite with a Broken String-The Balanced Scorecard. Balanced Scorecard Institute. Retrieved from http://www.balancedscorecard.org/Resources/Articles-White-Papers

Cooper, E. (2017). Corporate Social Responsibility, Gender, and CEO Turnover. Managerial Finance, 43(5), 528-544. https://doi.org/10.1108/MF-02-2016-0049

El Khatib, K. (2015). The Harms of the Benefit Corporation. American University Law Review, 65(1), 151-189.

ElAlfy, A., Palaschuk, N., El-Bassiouny, D., Wilson, J., \& Weber, O. (2020) Scoping the Evolution of Corporate Social Responsibility (CSR) Research in the Sustainable Development Goals (SDGs) Era. Sustainability, 12(14), 5544. https://doi.org/10.3390/su12145544

Elkington, J. (1997). Cannibals with Forks: The Triple Bottom Line of the 21st Century Business. Gabriola Island, BC: New Society Publishers. 
Ferrell, O. C., Thorne, D., \& Ferrell, L. (2016). Business and Society a Strategic Approach to Social Responsibility \& Ethics (5th ed.). Chicago Business Press.

Freeman, R. E. (1983). Stockholders and stakeholders: A new perspective on corporate governance. California Management Review (Pre-1986), 25(3), 88. https://doi.org/10.2307/41165018

Friedman, M (1970). The Social Responsibility of business is to increase its profits. The New York Times.

Gilbert, J. (2010, December 1). TEDxPhilly - Jay Coen Gilbert - On Better Businesses. Retrieved April 1, 2017 from https://www.youtube.com/watch?v=mGnz-w9p5FU

Hacker, M. A. (2016). Profit, People, Planet” Perverted: Holding Benefit Corporations Accountable to Intended Beneficiaries. Boston College Law School. Boston College Law Review, 57(5), 1747-1780.

Harrison, V. (2019). "It's a delicate dance": Understanding CSR relationships from the nonprofit perspective. Journal of Communication Management, 23(2), 142-158. https://doi.org/10.1108/JCOM-10-2018-0100

Hiralal, M. (2015). India: Corporate Social Responsibility - Indian Companies Act 2013. Retrieved from http://www.mondaq.com/india/x/366528/Corporate+Governance/Corporate+Social+Responsibility+Indian + Companies + Act +2013

Honeyman, R. (2015). A Look at the History of the B Corp Movement. Retrieved from http://www.triplepundit.com/2014/08/fascinating-look-history-b-corp-movement/

Horng, J.-S., Hsu, H., \& Chang-Yen, T. (2019) Learning corporate ethics and social responsibility: Developing an influential curriculum for undergraduate tourism and hospitality students. Journal of Hospitality, Leisure, Sports and Tourism Education, 24, 100-109. https://doi.org/10.1016/j.jhlste.2019.01.003

Howe, N., \& Strauss, W. (2000). Millennials Rising. New York: Vintage Books.

Kim, B.-J., Nurunnabi, M., Kim, T., \& Kim, T. (2018). Doing Good is Not Enough, You Should Have been Authentic: Organizational Identification, Authentic Leadership, and CSR. Sustainability, 10(6), 20-26. https://doi.org/10.3390/su10062026

Larrán, M., Andrades, J., \& Herrera, J. (2018). An examination of attitudes and perceptions of Spanish business and accounting students toward corporate social responsibility and sustainability themes Revista de Contabilidad. Madrid, 21(2), 196-205. https://doi.org/10.1016/j.rcsar.2018.02.001

Lopez, M., Garcia, A., \& Rodriguez, L. (2007). Sustainable Development and Corporate Performance: A Study Based on the Dow Jones Sustainability Index. Journal of Business Ethics, 75, 285-300. https://doi.org/10.1007/s10551-006-9253-8

Marques-Mendes, A., \& Santos, M. J. (2016). Strategic CSR: An Integrative Model for Analysis. Social Responsibility Journal, 12(2), 363-381. https://doi.org/10.1108/SRJ-04-2015-0055

McGlone, T., Spain, J., \& McGlone, V. (2011). Corporate Social Responsibility and the Millennials. Journal of Education for Business, 86(4), 195-200. https://doi.org/10.1080/08832323.2010.502912

Michelli, J. A. (2007). The Starbucks Experience. McGraw-Hill.

Miftachul, H., Mulyadi, D., Hananto, A. L., Nasrul, H. N. M., \& Kamarul, S. M. T. (2018). Empowering corporate social responsibility (CSR): insights from service-learning Social Responsibility. Bingley, 14(4), 875-894. https://doi.org/10.1108/SRJ-04-2017-0078

Porter, M. E., \& Kramer, M. R. (2011). Creating Shared Value. Harvard Business Review.

Post, J. E., Preston, L. E., \& Sachs, S. (2002). Redefining the corporation: Stakeholder management and organizational wealth. Stanford, CA: Stanford University.

Prutina, Z. (2016). The Effect of Corporate Social responsibility on Organizational Commitment. Journal of Contemporary Management, 21, 227-248.

Rao, K. T. C. (2016). Board Composition and Corporate Social Responsibility: The Role of Diversity, Gender, Strategy and Decision Making. Journal of Business Ethics, 138(2), 327-347. https://doi.org/10.1007/s10551-015-2613-5

Rausch, A. (2011). Reconstruction of decision-making behavior in stockholder and stakeholder theory: Implications for management accounting systems. Review of Managerial Science, 5(2-3), 137-169. https://doi.org/10.1007/s11846-010-0053-2

Reavis, M. R., Tucci, J. E., \& St. Pierre, G. (2017). Corporate Social Responsibility and Millennials’ Stakeholder 
Approach. Journal of Leadership, Accountability and Ethics, 14(4), $74-83$. https://doi.org/10.33423/jlae.v14i4.1488

Rogers, T., Jack, E. T., \& Mark, R. R. (2020). Imminent Changes in Corporate Strategic Financial Strategies: Millennial Women and the Their Stakeholder Value Approach. Journal of Contemporary Issues, 25(1).

Roker, A. (2017). Millennial Misconceptions-How They are Changing the Workplace. TODAY. New York City, NY: National Broadcast Corporation.

Serban, A. D. (2105). How Personal Values influence Romanian CSR manager's Involvement in CSR campaigns. Management Dynamics in the Knowledge Economy, 3(4), 729-748. https://doi.org/10.1007/s10551-014-2427-x

Sharp, K. (2014). Millennials' bold new business plan: Corporations with a conscience. Salon.com. Retrieved from http://www.salon.com/2014/02/09millennials_bold_new_business_plan_corporations_with_a_conscience/

Slaper, T., \& Hall, T. (2011). The Triple Bottom Line: What Is It and How Does It Work? Indiana Business Review, 86(1).

Smith, N. C., \& Rönnegard, D. (2016). Stockholder primacy, corporate social responsibility, and the role of business schools. Journal of Business Ethics, 134(3), 463-478.

Solomon, S. (2015). Idealism That May Leave Stockholders Wishing for Pragmatism. The New York Times. Retrieved from https://www.nytimes.com/2015/10/14/business/dealbook/laureate-education-for-profit-school-public-benefit .html? r $=0$

Starbucks 2012 Annual Meeting. (2013). Starbucks Annual Meeting. Retrieved from https://www.youtube.com/watch? $\mathrm{v}=\mathrm{hOIbHe} 0 \mathrm{I} 22 \mathrm{E} \& \mathrm{t}=9 \mathrm{~s}$

Stonkute, E., Vveinhardt, J., \& Sroka, W. (2018). Training the CSR Sensitive Mind-Set: The Integration of CSR into the Training of Business Administration Professionals. Sustainability, 10(3), 754. https://doi.org/10.3390/su10030754

Triple Bottom Line. (2009). The Economist. Retrieved from http://www.economist.com/node/14301663

Tucci, J. E., Shin, S., \& Benefield, M. (2015) Logistics Sustainability? Long Term Technology Investments and Integration. Journal of Management and Sustainability, 5, https://doi.org/10.5539/jms.v5n2p48

Wilburn, K., \& Wilburn, R. (2015). Evaluating CSR Accomplishments of Founding Certified B Corps. Journal of Global Responsibility, 6(2), 262-280. https://doi.org/10.1108/JGR-07-2015-0010

Winograd, M., \& Hais, M. (2014). How Millennials Could Upend Wall Street and Corporate America. The Brookings Institution. Washington, DC.

\section{Copyrights}

Copyright for this article is retained by the author, with first publication rights granted to the journal.

This is an open-access article distributed under the terms and conditions of the Creative Commons Attribution license (http://creativecommons.org/licenses/by/4.0/). 